\title{
Histone H3.Y
}

National Cancer Institute

\section{Source}

National Cancer Institute. Histone H3.Y. NCI Thesaurus. Code C155738.

Histone H3.Y (136 aa, $15 \mathrm{kDa}$ ) is encoded by the human H3.Y gene. This protein may be involved in both transcriptional regulation and the formation of higher order chromatin structures. 